Note

\section{Formation of Pimelic and Azelaic Acids, Biotin Intermediates, Derived from Oleic Acid by Micrococcus sp.}

\section{Masahiro OHSUGi and Yasuko INOUE}

\author{
Laboratory of Applied Microbiology, \\ Department of Food Science, \\ Faculty of Home Economics, \\ Mukogawa Women's University, \\ Nishinomiya 663 , Japan
}

Received March 16, 1981

The participation of oleic acid in biotin biosynthesis has not yet been elucidated. Our earlier investigation of the utilization of oleic acid by a strain of Brevibacterium sp. focused on the possibility that oleic acid could serve as a biotin intermediate to yield desthiobiotin. ${ }^{1)}$ After that we presented evidence of a role of oleic acid in biotin biosynthesis; the radioactivity of oleic acid- $-1{ }^{14} \mathrm{C}$ was incorporated into biotin-vitamers such as 7-keto-8-aminopelargonic acid, desthiobiotin and biotin by Cryptococcus neoformans. ${ }^{2)}$

In the course of our studies on microbial biotin biosynthesis, we have investigated a biotin intermediate with oleic acid by a strain of Micrococcus sp., which has already been reported by us as a bacterium forming pimelic acid from azelaic acid. ${ }^{3)}$ The evidence for the formation of pimelic acid from oleic acid is the subject of our report in this communication.

The organism was grown at $28^{\circ} \mathrm{C}$ for 4 days with shaking in a $500-\mathrm{ml}$ of a medium consisted of oleic acid ( $99 \%$ purity, Nakarai Chemicals) $0.5 \%,\left(\mathrm{NH}_{4}\right)_{2} \mathrm{SO}_{4} 0.3 \%$, $\mathrm{K}_{2} \mathrm{HPO}_{4} 0.2 \%, \mathrm{KH}_{2} \mathrm{PO}_{4} 0.2 \%$ and $\mathrm{MgSO}_{4} \cdot 7 \mathrm{H}_{2} \mathrm{O} 0.05 \%$ After growth, the cultures $(1,000 \mathrm{ml})$ were centrifuged to remove the cells, and concentrated to $110 \mathrm{ml}$ under reduced pressure at $40^{\circ} \mathrm{C}$. The small amount of a biotinvitamer in the concentrate was found by assay with Saccharomyces cerevisiae, in a concentration of $1.5 \mu \mathrm{g}$ per $1 \mathrm{ml}$. Desthiobiotin was identified as a product derived from oleic acid by paper chromatography used Toyo Roshi \# 53 paper and a butanol-acetic acid- $\mathrm{H}_{2} \mathrm{O}(12: 3: 5$ $\mathrm{v} / \mathrm{v})$ solvent, and bioassay. In order to remove the biotinvitamer, the concentrate was adjusted to $\mathrm{pH} 2$ with conc. $\mathrm{HCl}$ and the vitamer was filtered off with adsorption on $3 \mathrm{~g}$ of active carbon. The resulting filtrate was extracted three times with a $100 \mathrm{ml}$ volume of ether. The extract was again evaporated to dryness under vaccum. The residue was dissolved in $10 \mathrm{ml}$ of $\mathrm{H}_{2} \mathrm{O}$ and adjusted to $\mathrm{pH} 7.0$ with $4 \mathrm{~N}$ $\mathrm{KOH}$ (Sample I). A $0.5-\mathrm{ml}$ aliquot of Sample I was subjected to methylation with $\mathrm{BF}_{3}$-methanol reagent, ${ }^{4)}$

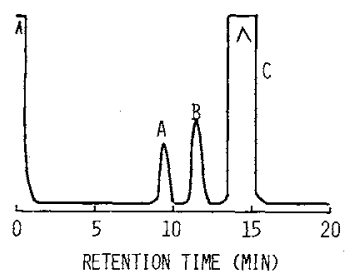

FIG. 1. Gas-liquid Chromatogram of Sample I.

The conditions of GLC were as follows: instrument, Shimadzu GC-4BP (FID); column, a glass column ( $3 \mathrm{~mm}$ i.d. $\times 2.0 \mathrm{~m}$ ) packed with $10 \%$ DEGS on Shimalite $W$ $(60 \sim 80 \mathrm{mesh})$; column temp., initial $100^{\circ} \mathrm{C}$, final $200^{\circ} \mathrm{C}$; programming rate, $5^{\circ} \mathrm{C} / \mathrm{min}$; injection and detector temp., $240^{\circ} \mathrm{C}$; carrier gas, nitrogen at $60 \mathrm{ml} / \mathrm{min}$; hydrogen, $50 \mathrm{ml} / \mathrm{min}$; air, $800 \mathrm{ml} / \mathrm{min}$; sensitivity $\times$ range, $10^{2} \times 64$ $\left(1.6 \times 10^{-9}\right.$ ampere in full scale). Each peak was identified as shown in the figure: A, pimelic acid; B, azelaic acid; C, oleic acid.

and analyzed by gas-liquid chromatography (GLC). The result is shown in Fig. 1. The two peak (compounds $A$ and $\mathrm{B}$ in figure) were separated on DEGS $10 \%$ column (Shimadzu), where the retention times of $9.4 \mathrm{~min}$ and 11.5 min, were marked respectively. The peaks eluting early (compound A), and another (compound B), were shown to be identical with authentic pimelic and azelaic acids, respectively. The conversion of oleic acid to azelaic and pimelic acids was quantitated by GLC and found in about 2.8 and 1.1 per cent yields, respectively. These low values for the conversion can probably be ascribed to the subsequent utilization of the intermediates during cultivation. Furthermore, the separation and identification of compounds $A$ and $B$ by GLC were achieved under the same conditions on two types of columns such as Shinchrome E71 and Fon (both Shimadzu), where the retention times of $9.2 \mathrm{~min}$ and $11.2 \mathrm{~min}$ on the former column, $11.5 \mathrm{~min}$ and 16.2 min on the latter, were marked respectively.

Compound A was characterized with the resting cell system of Bacillus sphaericus to form a biotin-vitamer, desthiobiotin. ${ }^{5)}$ Various amounts of Sample I were incubated with $48 \mathrm{mg}$ resting cells in $200 \mathrm{~mm}$ phosphate buffer ( $\mathrm{pH} \mathrm{7.0)}$ for 2 hours at $28^{\circ} \mathrm{C}$ under shaking. The volume of Sample I was varied from 0.01 to $0.3 \mathrm{ml}$ per $1 \mathrm{ml}$ of the reaction solution. Desthiobiotin synthesized was determined by assay with Saccharomyces cerevisiae. ${ }^{6)}$ The desthiobiotin yields at $0,0.01,0.03,0.1$ and $0.3 \mathrm{ml}$ Sample I were $0,0.015,0.03,0.11$ and $0.28 \mu \mathrm{g}$ per $\mathrm{ml}$, respectively. This result shows that the formation of desthiobiotin is directly proportional to the amount of Sample I introduced into the assay solution. Therefore, the above result does provide evidence for the presence of pimelic acid in Sample I. The organism, as described in the previous report, ${ }^{3)}$ possesses the ability to act on azelaic acid and form pimelic acid, so that the last step is undoubtedly attributable to a $\beta$-oxidation reaction which results in the formation of pimelic acid from azelaic acid. 
The mechanism of the formation of azelaic acid is under investigation.

\section{REFERENCES}

1) M. Ohsugi, Han-Chul Yang and K. Ogata, Agric. Biol. Chem., 36, 1285 (1972).

2) M. Ohsugi and Y. Ishikawa, Agric. Biol. Chem., 39, 559 (1975).
3) K. Ogata, T. Tochikura, M. Ohsugi and S. Iwahara, Mem. Res. Inst. Food Sci. Kyoto Univ., 26, 18 (1965); Agric. Biol. Chem., 30, 176 (1966).

4) W. R. Morrison and L. M. Smith, J. Lipid Res., 5, 600 (1964).

5) S. Iwahara, T. Tochikura and K. Ogata, Agric. Biol. Chem., 30, 1079 (1966).

6) E. E. Snell, R. E. Eakin and R. J. Williams, J. Am. Chem. Soc., 62, 175 (1940). 